\title{
The transition to reproductive senescence is characterized by increase in A6 and AVPV neuron activity with attenuation of noradrenaline content
}

\author{
Angela Cristina Nicola ${ }^{\mathrm{a}, \mathrm{c}}$, Cristiane Mota Leite $^{\mathrm{b}}$, Mariane Mayumi Batista Nishikava ${ }^{\mathrm{c}}$, \\ João Cesar Bedran de Castro ${ }^{\text {a,c }}$, Janete Aparecida Anselmo-Franci ${ }^{\text {b }}$, Rita Cássia Menegati Dornelles ${ }^{\text {a,c,* }}$ \\ a Programa Multicêntrico de Pós-Graduação em Ciências Fisiológicas - SBFis/UNESP, Brazil \\ b Laboratory of Neuroendocrinology, School of Dentistry of Ribeirão Preto, Universidade de São Paulo, Ribeirão Preto, SP, Brazil \\ c Laboratory of Endocrine Physiology and Aging, Araçatuba Dental School, Universidade Estadual Paulista, Araçatuba, SP, Brazil
}

\section{A R T I C L E I N F O}

\section{Article history:}

Received 7 December 2015

Received in revised form 10 March 2016

Accepted 19 April 2016

Available online 21 April 2016

Section Editor: Christian Humpel

\section{Keywords:}

Reproductive aging

Locus coeruleus

Preoptic area

GnRH

Noradrenaline

\begin{abstract}
A B S T R A C T
During the course of life, cyclic females face a state of midlife transition that occurs in a fully functioning neurological system, and results in reproductive senescence. The authors' hypothesis was that changes in the activity noradrenergic neurons may be one of the factors involved in this phenomenon. The aim of this study was to investigate the activity of the neurons in the anteroventral periventricular nucleus (AVPV) and locus coeruleus (LC), to analyze their role in determining reproductive senescence. Adult female Wistar rats in the diestrus phase (4 months/cyclic) and old females (18-20 months/acyclic) in persistent diestrus, were decapitated or perfused at three different time intervals $(10,14$ and $18 \mathrm{~h})$ throughout the day. In acyclic rats, the gonadotropinreleasing hormone $(\mathrm{GnRH})$ and noradrenaline (NE) content were reduced; Fos-related antigen (FRA) in AVPV and Fos-related antigen/Tyrosine hydroxylase (FRA/TH) in LC showed immunolabeling of a higher number of neurons in these animals. The 3-methoxy-4-hydroxyphenylglycol/noradrenaline (MHPG/NE) ratio was higher and plasma LH was lower in the acyclic rats. Furthermore, the estradiol level was higher, and the progesterone level was lower after $14 \mathrm{~h}$ of persistent diestrus. These findings suggested that during the periestropause, there was a higher level of POA/AVPV and NE neuronal activity in the LC of acyclic rats, associated with a lower capacity of synthesis and storage of neurotransmitters and neurohormones contributed to changes in the temporal pattern of neuroendocrine signaling, thereby compromising the accuracy of inhibitory and stimulatory effects, causing irregularity in the estrous cycle and determining reproductive senescence
\end{abstract}

(c) 2016 Elsevier Inc. All rights reserved.

\section{Introduction}

The state of transition in cyclic females, such as perimenopause, is characterized by an integrated series of phase-dependent transformations that involve sequential activation and deactivation of complex regulatory pathways (Petricka and Benfey, 2011). With advanced female aging, there are further reproductive changes, typically a loss of reproductive capacity with partial or complete reproductive senescence. During this process, each level of the hypothalamic-pituitarygonadal (HPG) axis undergoes changes in structure, function, and hormone synthesis/release (Wang et al., 2015). All women who reach the age of 60 years with their reproductive organs intact will go through perimenopause to menopause with duration of 1-5 years from start to completion (Brinton, 2010; Harlow et al., 2012). These states of transition are associated with regulatory network restructuring that leads to reproductive senescence, and in the females of most species, this results

\footnotetext{
* Corresponding author at: Department of Basic Sciences, Building 31, UNESP, Rodovia Marechal Rondon Km 527, 16018-805 Araçatuba, SP, Brazil.

E-mail address: rcdfisio@foa.unesp.br (R.C.M. Dornelles).
}

from changes in the HPG axis (Brann and Mahesh, 2005; Downs and Wise, 2009; Neal-Perry et al., 2010).

Rodent and nonhuman primates, and humans share the common features of perimenopausal transition, with irregular cycling and fertility, steroid hormone fluctuations and lower sensitivity to estrogen (Diaz Brinton, 2012; Finch, 2014). Delayed onset and attenuated amplitude of the preovulatory LH surge, in rodents, occurs from 8-12-months of age and extends up to 18 months, when the persistent diestrus phase begins, after a brief period of constant estrus (Ferreira et al., 2015), and characterizes onset of reproductive senescence (Acuña et al., 2009; Cora et al., 2015). However, acyclic rodents are able to return ovarian function in response to stimuli in gonadotropin releasing hormone ( $\mathrm{GnRH}$ ) neurons (Campos and Herbison, 2014), suggesting that neuroendocrine components contribute to determining the reproductive aging (Cashion et al., 2003; Franceschini and Desroziers, 2013; MohanKumar and MohanKumar, 2004). Attenuated GnRH neurosecretion from the medial basal hypothalamus (MBH) (Rubin, 2000), and altered secretion of neurotransmitters such as glutamate (Neal-Perry et al., 2005); GABA (Mitsushima et al., 2002); noradrenaline (NE) (MacKinnon et al., 1983); and kisspeptin (Dungan et al., 2007; 
Gianetti and Seminara, 2008), may be associated with the female states of transition (Le et al., 2001).

The important action of the NE in controlling the preovulatory $\mathrm{LH}$ surge of reproductive-aged rodents occurs via the preoptic area (POA), principally the anteroventral periventricular (AVPV) nucleus, that receives projections of noradrenergic neurons from the locus coeruleus (LC), A1 and A2 (Campbell and Herbison, 2007; Szawka et al., 2009; Williams and Kriegsfeld, 2012). Electrolytic lesions in the LC decrease $\mathrm{NE}$ content in the medial POA and MBH, disrupt the estrous cycle and block the preovulatory surge of gonadotropin (Anselmo-Franci et al., 1997). Moreover, several studies have shown the participation of NE in the $\mathrm{GnRH} / \mathrm{LH}$ surge during the reproductive period. Nevertheless, this has not been elucidated during the state of transition from the cyclic to acyclic stage, characterized by the non-occurrence of the LH surge. The authors hypothesized that in the aging female, changes in the activity noradrenergic neurons may be one of factors involved in determining the reproductive senescence.

Therefore, the authors analyzed and compared the activity of AVPV neurons and noradrenergic neurons of the LC; concentrations of the NE and 3-methoxy-4-hydroxyphenylglycol (MHPG)/NE ratio, in addition to the GnRH content in the MBH of cyclic adult rats, in diestrus, and in persistent diestrus of acyclic old rats, in order to elucidate their participation in reproductive aging. The authors performed in vivo experiments using rats in natural aging to analyze the real changes that occurred in this period and determined reproductive senescence.

\section{Methods}

\subsection{Animals}

Ninety-six female rats of the Wistar strain, aged 4 months (adultcyclic) and 18-20 months (old-acyclic), were housed in plastic cages, in groups of four, in a temperature-controlled room $\left(22 \pm 2{ }^{\circ} \mathrm{C}\right)$ with a 12/12 h light/dark cycle (lights on at 7:00 h). Food and water were provided ad libitum. Vaginal smears were taken daily for analysis of the estrous cycle. Animal experiments were carried out in accordance with the laboratory principles of animal care (Council, 2011) and were approved by the local Ethics Committee for Research Involving Animals of the University Estadual Paulista (CEUA: 01829-2011). Only adult rats (4 months) showing normal estrous cycles, and old rats (1820 months) in persistent diestrus, showing at least three consecutive cycles, were used in this study. The criteria for inclusion in this study were: the use of only multiparous female rats and those in the diestrus phase. All female rats were sacrificed at 10,14 and $18 \mathrm{~h}$ on the diestrus day, in order to estimate neuronal activity of both the AVPV and LC, by using FOS protein expression as a marker of neuronal activity in the period important for change in the LH during the proestrus period of cyclic rats. The rats appeared to be healthy, and showed no anatomic pathological abnormality on the day of sampling.

\section{Experimental design}

\subsection{Experiment 1: noradrenaline content and hormone profile}

Forty-eight diestrus rats and those in persistent diestrus were decapitated ( $\mathrm{n}=8$ /group) for blood collection, removal and immediate freezing of their brains. Noradrenaline concentrations and GnRH content were measured in microdissections from the POA and $\mathrm{MBH}$. NE, its metabolite and NE turnover rate, estimated by the MHPG/NE ratio, were determined by high-performance liquid chromatography with electrochemical detection (HPLC-ED). Plasmatic concentration of the LH, FSH, estradiol and progesterone was determined by radioimmunoassay.

\subsubsection{Brain microdissection}

Coronal brain sections were obtained by using a cryostat at $-15^{\circ} \mathrm{C}$ (Microm ${ }^{\circledR}$ HM 505) according to the rat brain atlas (Paxinos and
Watson, 2007). One section of $1500 \mu \mathrm{m}$ and two consecutives sections of $1000 \mu \mathrm{m}$ were obtained by microdissection by using the punch technique (Palkovits, 1973). The POA was microdissected from the first section (approximately $+0.48 \mathrm{~mm}$ from the bregma until $-1.08 \mathrm{~mm}$ ), in one punch obtained with a $2.0 \mathrm{~mm}$ diameter needle, centered immediately above to the optic chiasm. The MBH was microdissected from the second and third sections, starting at approximately -1.8 and $-2.8 \mathrm{~mm}$ from the bregma, respectively, in one punch bilaterally obtained with a $1 \mathrm{~mm}$ 'square puncher', centered on the third ventricle.

\subsubsection{HPLC-ED}

To analysis of concentrations of NE and metabolites in POA, by HPLC$\mathrm{ED}$, the samples were mixed with $100 \mu \mathrm{L}$ of perchloric acid (PCA $0.15 \mathrm{M}$ ) and ethylene diaminetetraacetic acid (EDTA $0.1 \mathrm{mM}$ ) containing $10 \mathrm{pg} / \mu \mathrm{L}$ of isoproterenol (ISOP) as internal standard. The homogenate was centrifuged (13.000 rpm $\left./ 5 \mathrm{~min} / 4^{\circ} \mathrm{C}\right)$, filtered ( $0.22 \mu \mathrm{m}$ membrane; Durapore, Millipore) and hydrolyzed by heating to $94^{\circ} \mathrm{C}$ for $5 \mathrm{~min}$ (Lookingland et al., 1991) before being injected into the HPLC-ED system by means of an autoinjector (SIL-10Advp; Shimadzu, Kyoto, Japan). Separation was performed at $35^{\circ} \mathrm{C}$ in a $250 \times 4$-mm RP-18e column (Purospher, $5 \mu \mathrm{m}$; Merck, Darmstadt, Germany), preceded by a $4 \times 4$-mm RP-18e guard column (Lichrospher, $5 \mu \mathrm{m}$; Merck). The mobile phase consisted of $100 \mathrm{mM}$ sodium dihydrogen phosphate, $15 \mathrm{mM}$ sodium citratum, $10 \mathrm{mM}$ sodium chloride, $0.1 \mathrm{mM}$ EDTA, $0.4 \mathrm{mM}$ sodium 1-octanesulphonic acid (SigmaAldrich) and 16\% methanol (Omnisolv; EMD Chemical Inc., Gibbstown, NJ, USA) ( $\mathrm{pH}$ 3.5). The pump (LC-10Advp; Shimadzu) flow rate was set at $0.4 \mathrm{~mL} / \mathrm{min}$, and the detector potential was $0.75 \mathrm{~V}$ (Decade; Antec, Leyden, The Netherlands). Chromatography data were plotted with the Class-VP software program (Shimadzu). Noradrenaline and MHPG were identified by their peak retention time and quantified by the internalstandard method based on the area under the peak. All samples from each brain area were measured in the same analysis. The intra-assay coefficient of variation was $0.96 \%$ for NE and $4.6 \%$ for MHPG. The NE level was considered to estimate the neurotransmitter contained in synaptic vesicles, whereas the MHPG level reflected the amount NE released in the sample (Lookingland et al., 1991). The MHPG/NE was used as a measure of neurotransmitter turnover. In the remaining pellet, the protein content was determined by the Bradford method (Bradford, 1976). The catecholamine content was expressed in $\mathrm{pg} / \mu \mathrm{g}$ protein.

\subsubsection{Radioimmunoassay}

MBH samples were sonicated ( $50 \mu \mathrm{L} \mathrm{HCl}$ ), and centrifuged $\left(12,000 \mathrm{rpm} / 20 \mathrm{~min} / 4^{\circ} \mathrm{C}\right.$; Eppendorf ${ }^{\circ}$, Model $\left.5417 \mathrm{R}\right)$ to determine the GnRH content. Antibody GnRH R1245 was used, produced by Terry Nett (Department of Biomedical Sciences, Colorado State University, CO, USA); standard INC was supplied by Peninsula Laboratories (Bachem Inc., CA, USA), and hormone marked $\left({ }^{125} \mathrm{I}\right)$ by PerkinElmer (NEX-10 $\mu$ Ci 1630, PerkinElmer Life and Analytical Sciences, MA, USA). All dilutions were made in a phosphate buffer gel containing EDTA (pH 7.4), at $4{ }^{\circ} \mathrm{C}$. The complex was precipitated with cold absolute ethanol and the lowest limit of detection was $0.24 \mathrm{pg} / \mathrm{mL}$. The radioactivity of the precipitate was determined by using a gamma counter (Wizard 1470 Automatic Gamma Counter, Perkin Elmer) and the results were expressed as $\mathrm{pg} / \mathrm{mg}$ protein in the $\mathrm{MBH}$ determined by protein assay (Bradford, 1976).

Plasma LH and FSH levels were determined by double-antibody RIA using the specific kit provided by the National Institute of Diabetes, Digestive and Kidney Diseases (NIDDK, Bethesda, MD, USA). The antibodies used were anti-rat LH-S10 and FSH-S11 diluted with normal rabbit serum and standard preparation LH-RP3 and FSH-RP2 diluted in phosphate buffered gel $0.1 \%(0.01 \mathrm{M}, \mathrm{pH}=7.5)$. The minimum detectable dose was $0.16 \mathrm{ng} / \mathrm{mL}$ for $\mathrm{LH}$, and $0.09 \mathrm{ng} / \mathrm{mL}$ for FSH and the intra-assay coefficient of variation was $4 \%$.

Progesterone was determined using a kit from MP Biomedicals LLC (Divisions Diagnostics, New York, USA); and for estradiol, the Siemens kit was used (Siemens Medical Solutions Dignostics, Los Angeles, 
USA). The minimum detectable dose of estradiol $(5.0 \mathrm{pg} / \mathrm{mL})$ and progesterone $(0.3 \mathrm{ng} / \mathrm{mL})$ and the intra-assay value for estradiol $(4.3 \%)$ and progesterone $(7.6 \%)$ were calculated. All samples were assayed in duplicate and in the same assay to avoid inter-assay error.

\subsection{Experiment 2: neuronal activity in the AVPV and noradrenergic neurons in the $L C$}

Forty-eight experimental animals ( $\mathrm{n}=8$ /group) were anaesthetized with a mixture of ketamine (Cetamin ${ }^{\circledR}$; Syntec, São Paulo, Brazil; $80 \mathrm{mg} / \mathrm{kg}$ body weight, i.p.) and xylazine (Xylazin ${ }^{\circledR}$, Syntec; São Paulo, Brazil; $8 \mathrm{mg} / \mathrm{kg}$ body weight, i.p.) and perfused transcardially. The procedure was performed with phosphate-buffered saline (PBS) with heparin ( $5 \mathrm{IU} / \mathrm{mL}$ ), followed by $4 \%$ paraformaldehyde in $0.1 \mathrm{M}$ phosphate buffer and the brains were processed as previously described (Helena et al., 2006; Szawka et al., 2005). Frontal sections of $30 \mu \mathrm{m}$ were cut in a cryostat approximately $+0.48 \mathrm{~mm}$ to -0.48 from bregma for POA; and $-9.36 \mathrm{~mm}$ to $+10.32 \mathrm{~mm}$ from bregma for LC, according to the atlas of Paxinos and Watson (Paxinos and Watson, 2007). Sections were collected in four adjacent series and stored at $-20{ }^{\circ} \mathrm{C}$ in culture dishes containing cryoprotectant solution (Watson et al., 1986) until the time of analysis. The sections were processed by immunohistochemistry for FRA (Fos) in the POA and FRA/TH in the LC. The number of FRA-ir and FRA/TH-ir neurons was analyzed bilaterally in the LC and AVPV as previously described (Leite et al., 2008).

\subsubsection{Immunohistochemistry}

Immunoperoxidase single labeling of FRA in sections from the AVPV, and double labeling of FRA/TH in sections from LC were performed as previously described (Helena et al., 2006; Leite et al., 2008; Szawka et al., 2005, 2013, 2009; Watson et al., 1986). After removal from the cryoprotectant solution, the sections were rinsed and incubated with anti-FRA rabbit antibody (K-25; Santa Cruz Biotechnology, Santa Cruz, CA, USA), at a dilution of 1:2000 for $40 \mathrm{~h}$. After this, biotinylated antirabbit goat immunoglobulin G (BA-1000; Elite Kit, Vector Laboratories, Burlingame, CA, USA) at 1:600 for $90 \mathrm{~min}$ and avidin-biotin complex solution at a dilution of 1:100 for $1 \mathrm{~h}$ (Elite $A B C$ kit, Vector Laboratories) were added. The antibody-peroxidase complex was visualized with a solution of nickel sulphate $(25 \mathrm{mg} / \mathrm{mL}), 3,3^{\prime}$-diaminobenzidine- $\mathrm{HCl}$ (DAB $0.2 \mathrm{mg} / \mathrm{mL}$ ) and $\mathrm{H}_{2} \mathrm{O}_{2}(1 \mu \mathrm{L} / \mathrm{mL}$ of $30 \%$ stock solution) in $0.175 \mathrm{M}$ acetate buffer ( $\mathrm{pH} 7.5$ ). Sections were then incubated with anti-TH mouse antibody (anti-TH2; Sigma, Saint Louis, MO,USA) at a dilution of 1:500.000 for $40 \mathrm{~h}$, followed by biotinylated horse anti-mouse horse immunoglobulin G (BA 2001; Vector Laboratories) at a dilution of 1:600 for $1 \mathrm{~h}$ and with Elite $A B C$ kit for $1 \mathrm{~h}$. TH was immunostained with a solution containing $\mathrm{DAB}(0.2 \mathrm{mg} / \mathrm{mL})$ and $\mathrm{H}_{2} \mathrm{O}_{2}(1 \mu \mathrm{L} / \mathrm{mL}$ of $30 \%$ stock solution) in $0.05 \mathrm{M}$ Tris-HCl buffer ( $\mathrm{pH}$ 7.6). Sections were mounted on glass slides, cover slipped with Entellan (Merck, Darmstadt, Germany) and stored until the time of analysis of the groups.

To analyze the delimited area of AVPV, the rostral-caudal pattern was identified as previously described (Le et al., 2001). Immediately afterwards, the authors proceeded with bilateral counts of FRA-ir neurons in a square area of $19.200 \mu \mathrm{m}^{2}(240 \times 716$ pixels $)$ and $28.800 \mu \mathrm{m}^{2}$ $(240 \times 956$ pixels), corresponding to the coordinates $0.00 \mathrm{~mm}$ and $-0.12 \mathrm{~mm}$ from bregma, respectively, using the third ventricle as the limit. In LC, double-labeled FRA/TH-ir neurons were bilaterally quantified, considering the coordinates $-9.36 \mathrm{~mm}$ to $-10.08 \mathrm{~mm}$ for all animals. The analyses were performed with an optical microscope (Axioskop 2 plus, Zeiss, Hallbergmoos, Germany) using the Axiovision 3.1 image analysis system (Zeiss).

\section{Statistical analysis}

According to the Shapiro-Wilk normality test, statistical differences were determined by two-way ANOVA using Sigma Plot v12.0 (SYSTAT, San Jose, CA, USA) followed by Newman-Keuls post-test for all the parametrical analyses. The relationship between the GnRH and NE content, as well as MHPG and estradiol were determined by means of the Spearman nonparametric correlation analysis. Mean values \pm SEM are expressed in the graphs. The level of significance was set at $p<0.05$ for all comparisons.

\section{Results}

To validate an appropriate model of reproductive senescence, the authors analyzed the changes occurring in the estrous cycle of the Wistar rats aged 18-20 months. They showed that initial change was marked by increased variability in the length of the estrous cycle phases, with diestrus lasting 12 days longer, similar to stage -2 in women, referred to as early menopausal transition (Harlow et al., 2012). This period
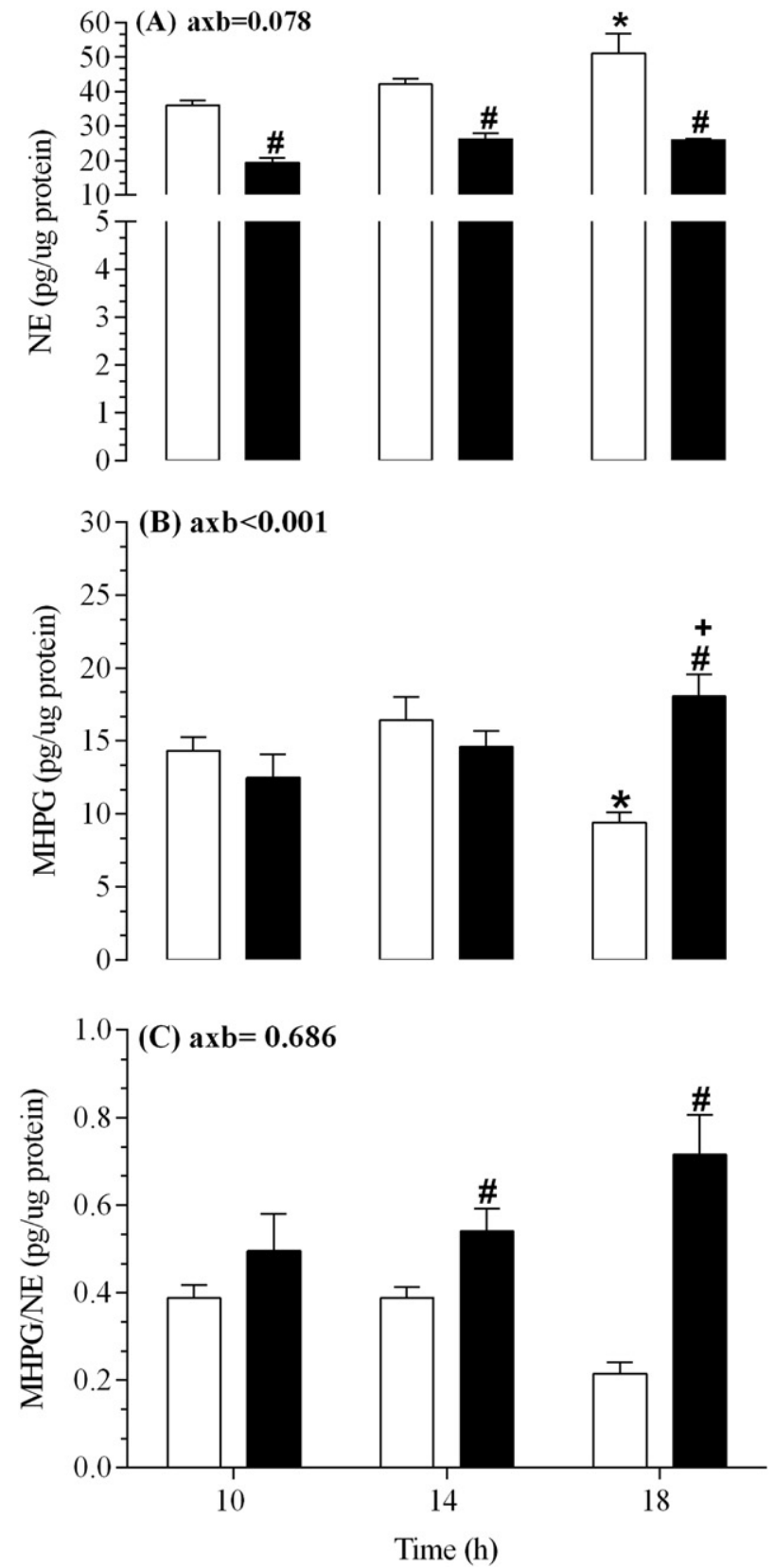

Fig. 1. The NE content (A), MHPG (B), MHPG/NE ratio (C), in the POA of adult-cyclic

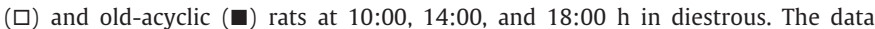
expressed as the mean \pm SEM. ${ }^{*} p<0.05$ vs. cyclic rats at the same time interval; ${ }^{*} p<0.05$ vs. $10: 00 \mathrm{~h}$ and $14: 00 \mathrm{~h} /$ cyclic rat; ${ }^{+} p<0.05 \mathrm{vs} .10: 00 \mathrm{~h}$ and $14: 00 \mathrm{~h} /$ acyclic rat; $\mathrm{axb}=$ interaction of age and time. 

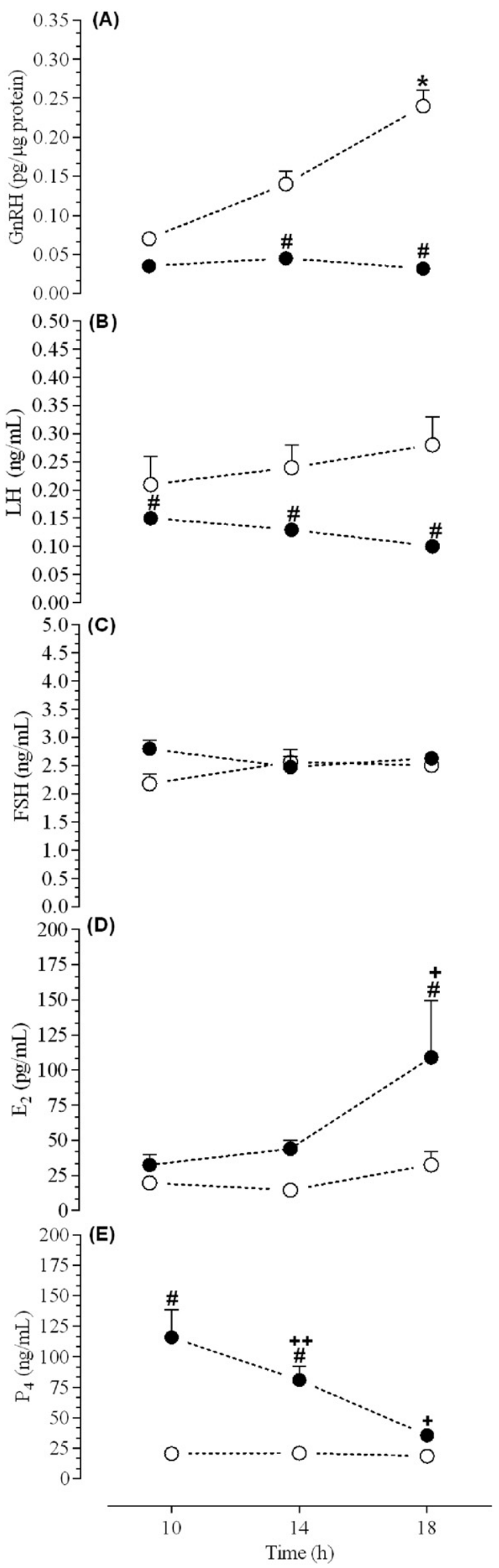

is defined as persistent diestrus with recurrence within 3 or 4 cycles with a variable length cycle. Transition early in the estrous cycle was also marked by decrease of the $\mathrm{LH}$, characterizing the period of periestropause in these animals. Regularity of the estrous cycle was confirmed in the rats aged 4 months.

\subsection{Noradrenaline content and hormone profile}

These experiments evaluated the effect of age-related on neurotransmitter (NE); GnRH content; gonadotropins, and ovarian steroids of the female rats. Statistical analysis of the NEs and their main metabolite (MHPG) throughout the extension of the POA pointed out interaction between the factors age and time for the metabolite $(p<0.001)$. The NE content demonstrated that the level of these neurotransmitters (Fig. 1A) stored in the acyclic group was constant and lower than it was in the cyclic group $\left(p<0.001 ; \mathrm{F}_{(1,27)}=126.012\right)$, indicating a lower rate of NE synthesis in these animals. In the cyclic group an increased in this content was observed over time $\left(p_{10} \times 18 \mathrm{~h}<0.001\right.$ and $p_{14 \times 18 \mathrm{~h}}<0.05$ ).The MHPG metabolite content (Fig. 1B) showed significant differences at 18:00 $\mathrm{h}$ in both groups $\left(\mathrm{F}_{(1,26)}=2.697\right)$, when intragroup comparisons $(p<0.01)$, and comparisons between cyclic and acyclic groups $(p<0.001)$ were made. In this time interval, the metabolite content was greater in older animals $(p<0.05)$. The release rate of the noradrenergic ratio MHPG/NE (Fig. 1C) was higher at 14:00 $(p<0.05)$ and 18:00 h $(p<0.05)$ in the acyclic group compared with the respective time intervals of the cyclic group $\left(F_{(1,24)}=11.703\right)$.

In the group of the cyclic rats, the GnRH content increased significantly at $18 \mathrm{~h}\left(p_{10 \times 18 \mathrm{~h}}<0.01\right)$, and the plasma concentration of $\mathrm{LH}$ and FSH did not change during the same period (Fig. 2A, B and C). No effects of time of day were found in persistent diestrous rats as regards the GnRH content in the MBH, and LH and FSH plasma levels. However, in comparison with adult rats, the MBH GnRH content in the old rats was lower at 14:00 $\mathrm{h}(p<0.05)$ and 18:00 $\mathrm{h}\left(p<0.001 ; \mathrm{F}_{(1,24)}=21.104\right)$ and LH plasma levels were lower in all time intervals studied $\left(p<0.05\right.$ at $10: 00$ and $14: 00 \mathrm{~h} ; p<0.001$ at $18: 00 \mathrm{~h} ; \mathrm{F}_{(10,230)}=$ 29.736). The interaction between the factors age and time considering the hormonal parameters proved to be significant for the GnRH $(p<0.05)$. Furthermore, no differences were observed between FSH of the adult and old rats $\left(p=0.134 ; F_{(1,28)}=1.877\right)$.

Fig. 2D shows the plasma estradiol levels as measured by RIA for intact female Wistar rats. A significant effect of time of day was observed, owing to significantly higher estradiol levels at 18:00 h than at 10:00 h $(p<0.01)$ and $14: 00 \mathrm{~h}(p<0.05)$ in acyclic rats. There was no effect of time of day on estradiol levels in these cycling animals, or any interaction of time of day with cycling status or age. Post-hoc analysis indicated that estradiol levels were significantly higher at 18:00 $\mathrm{h}$ in persistent diestrus than in diestrous rats $(p<0.05)$. A significant effect of age on plasma progesterone levels was observed with significantly higher levels in acyclic than in cyclic rats $(p<0.001)$. In cycling (diestrus) rats, no significant effect of age and time of day on progesterone levels were observed (Fig. 2E). In acyclic rats (persistent diestrus), a significant effect of time of day was observed, owing to significantly higher progesterone levels at 10:00 h $(p<0.001)$ and 14:00 $\mathrm{h}(p<0.01)$ than at 18:00 h. Posthoc analysis indicated that progesterone levels were significantly higher in persistent diestrus than in diestrous rats $(p<0.05)$. The authors point out that ovarian steroids in acyclic rats were inversely proportional to each other (Fig. 2D and E), i.e. the estradiol levels increased while the progesterone levels decreased during the course of the time intervals studied on the persistent diestrus day.

Fig. 2. The hypothalamic GnRH content (A), plasma levels of gonadotropins (B and C) and sex-steroid levels (D and E) of adult-cyclic $(O)$ and old-acyclic $(\bullet)$ rats. All the data are expressed as the mean \pm SEM. ${ }^{*} p<0.05$ vs. cyclic rats at the same time interval; ${ }^{*} p<0.05$ vs. $10: 00 \mathrm{~h}$ and $14: 00 \mathrm{~h} /$ cyclic rat; ${ }^{+} p<0.05$ vs. $10: 00$ and $14: 00 \mathrm{~h} /$ acyclic rat; ${ }^{++} p<0.05$ vs. $10: 00 \mathrm{~h} /$ acyclic rat; axb $=$ interaction of age and time. 
The variables for NE (POA) and $\mathrm{GnRH}(\mathrm{MBH})$ content, as well as MHPG/NE (POA) and plasma $E_{2}$ for both adult and old rats, revealed a positive correlation (Fig. $3 \mathrm{~A} \mathrm{r}_{\mathrm{S}}=0.74$ and $3 \mathrm{C} ; \mathrm{r}_{\mathrm{S}}=0.4866$; $\left.p^{<} 0.0001\right)$. However, comparisons between MHPG/NE and LH plasmatic were negatively correlated (Fig. $3 \mathrm{~B} ; \mathrm{r}_{\mathrm{S}}=-0.6311 ; p<0.001$ ).

\subsection{Neuronal activity in the AVPV and noradrenergic neurons in the $L C$}

This purpose of this experiment was to determine the specific activity of AVPV neurons and noradrenergic neurons in the LC during the
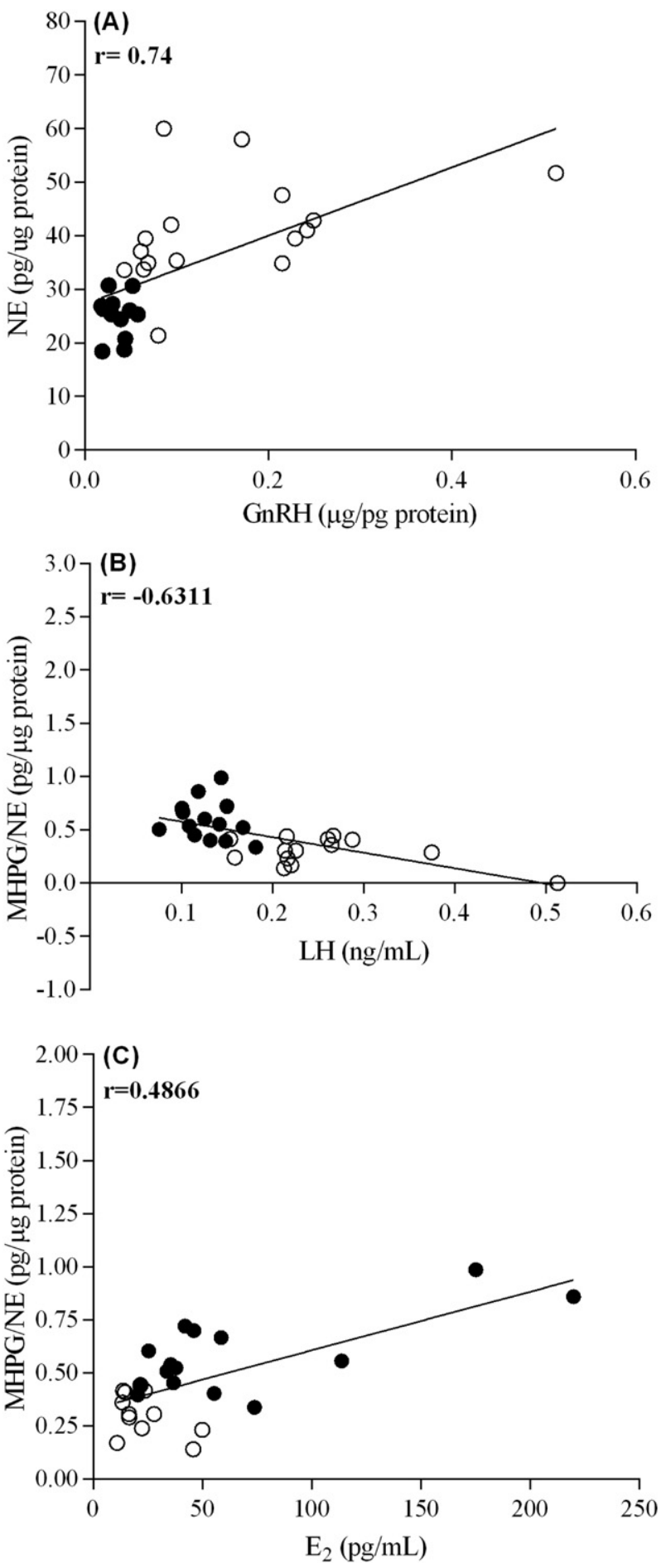

Fig. 3. Spearman nonparametric correlations analysis between neurotransmitter, GnRH, $\mathrm{LH}$ and $\mathrm{E}_{2}$ of adult-cyclic $(\mathrm{O})$ and old-acyclic $(-)$ rats. (A and $\mathrm{C}$ ) Positive and (B) negative correlations. $\mathrm{r}=$ correlation coefficient. aging of the female rats. The level of FRA-ir expression in the AVPV neurons of acyclic rats was higher at 14 and $18: 00 \mathrm{~h}\left(p<0.001 ; \mathrm{F}_{(1,24)}=\right.$ $71.608)$ when compared with the same time intervals in cyclic rats $(p<0.001)$. No difference was observed between cyclic rats, as shown in Fig. 4G. Illustrative photomicrographs of nuclear-labeling of Fosrelated antigen (FRA) in the AVPV (Fig 4A) of cyclic rats (Fig. 4B-C) perfused at 18:00 h, demonstrating less intense FRA activation of AVPV neurons when compared with acyclic rats (Fig. 4D-F). Fig. 5 shows FRA/TH-ir expression by neurons in LC in the diestrus phase. Doublelabeled cells were identified as those that exhibited brown cytoplasmic stain and a black nucleus. The results (Fig.5G) demonstrated a higher level of expression at 10 and $14: 00 \mathrm{~h}\left(p<0.05 ; \mathrm{F}_{(1.26)}=23.763\right)$ in acyclic rats when compared with same time intervals in cyclic rats. In this analysis, there was no interaction between the factors age and time $(p=0.498)$. Fig. 5A-C and D-F display representative photomicrographs of FRA/TH-ir neurons in the LC of cyclic and acyclic rats, respectively, perfused at 10:00 $\mathrm{h}$ in diestrus.

\section{Discussion}

This study demonstrated that NE plays a role in regulating the neuroendocrine status present in acyclic rats. The authors' results showed age-related increase in the activity of neurons in the LC and POA/ AVPV, and in the turnover of NE, but decrease in content of NE, GnRH and plasma concentration of LH in acyclic female rats. However, in adult cyclic rats, they found an increase in the NE and GnRH content in POA/AVPV, indicating involvement of this neurotransmitter in the neuroendocrine events to induce the pre-ovulatory LH surge and ovulation.

In the reproductive cycles of rats, the importance of $\mathrm{NE}$ in inducing the LH surge was clearly established. There was evidence of direct action, mediated by both $\alpha 1$ and $\beta$ - adrenergic receptors in the soma and/or dendrites, and of indirect action of NE on releasing hormonecontaining neurons (Han and Herbison, 2008; Hosny and Jennes, 1998; Szawka et al., 2013). Noradrenergic involvement of the brainstem neuron groups located in A1/A2 (Herbison, 1997; Ibrahim and Briski, 2014) and A6 (Anselmo-Franci et al., 1997, 1999; Berridge and Waterhouse, 2003; Wang et al., 2015) to hypothalamus neurons has been demonstrated to be a source and trigger of the $\mathrm{GnRH} / \mathrm{LH}$ mediated pre-ovulatory surge increased by gonadal steroids. The role of NE in reproductive-aged rodents is evident, and is associated with ovarian steroids in regulating the secretion of hypothalamic $\mathrm{GnRH}$ through neurotransmitters, and with the neural events that induce the LH surge (Helena et al., 2006). Furthermore, estradiol and progestin receptors in LC neurons suggest that these cells are responsive to variations in circulating levels of ovarian steroids (Szawka et al., 2009). The authors' results showed the actions previously described (Sellix and Menaker, 2011) with regard to effects of gonadal steroids on gonadotropin secretion in estrous cyclicity. In cyclic rats, the diestrus phase is characterized by constant concentrations of LH (Fig. 2B) and gonadal steroids (Fig. 2D-E), over the course of the time intervals analyzed in accordance with the present study.

There is evidence that aging of the neuroendocrine components of the reproductive axis in women is characterized by a decrease in the frequency of pulsatile GnRH (Hall et al., 2000) and pituitary responsiveness (Shaw et al., 2009). In the late 80s, a study in rodents, (Rubin and Bridges, 1989) showed that in old females, there was a lower volume in the Golgi apparatus and rough endoplasmic reticulum in the $\mathrm{GnRH}$ neurons; some years later, changes were shown in the morphology, cytoarchitecture, and ultrastructure of GnRH perikarya and terminal (Yin et al., 2009). In the present study, the authors showed a lower GnRH content and plasma LH level (Fig. 2A, B), but the level of gonadal steroids was higher in persistent diestrous (Fig. 2D, E) when compared with that of adult rats on the diestrous day. These results suggest that the negative feedback of estradiol prevailed in the GnRH neuron and indicated that biosynthetic capacity of gonadal was maintained for a 

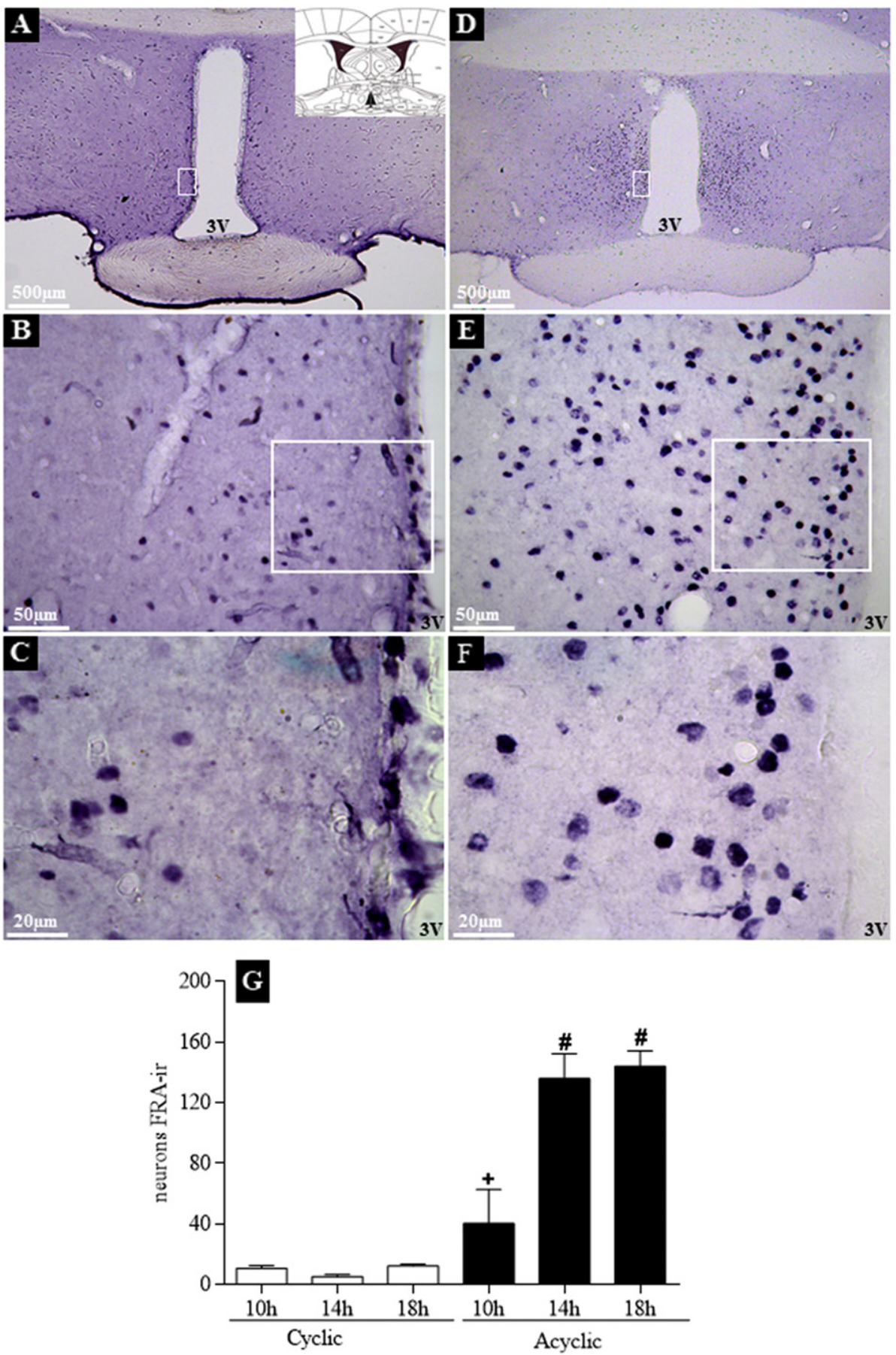

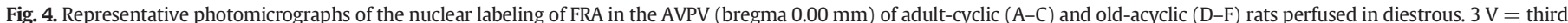

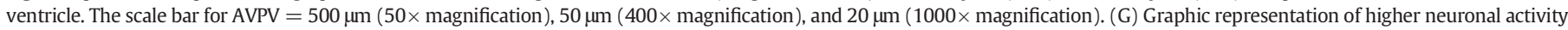

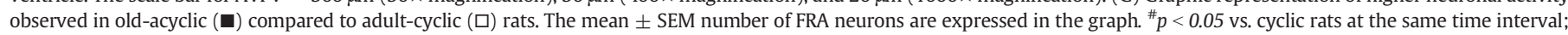
${ }^{+} p<0.05$ vs. $14: 00$ and $18: 00 \mathrm{~h} /$ acyclic rat.

long period during aging. It is interesting that the neurophysiological pathways responsible for generating the LH surge is dependent on endogenous ovarian steroids and these exert their effects on monoaminergic systems, changing the levels of enzymes that synthesize and degrade NE (Donner and Handa, 2009). Levels of monoamine reuptake transporters and receptors (Le Saux et al., 2006; Osterlund et al., 2000) and coupling of receptors to intracellular second messenger systems are also influenced by estradiol (Mize and Alper, 2002; Mize et al., 2001). It is important to point out that in young and adult rats, estradiol levels are higher than they are in old rats and the effect of aging on estrogen negative feedback on LH is true across a range of low level of E2
(Shaw et al., 2011). In this study, the authors could observe that the configuration of graphs quantifying the activity of AVPV and LC neurons was similar to that of the plasma concentration of E2 and progesterone, respectively. Thus, the authors suggest that the increase in plasma steroid levels contributed to the high activity of AVPV and LC neurons and NE turnover rate during the persistent diestrus, but these neurons were less effective in the synthesis and storage of the neurotransmitters required for increasing GnRH and LH (Figs. 1-2). Furthermore, these results suggested that the properties of cells, such as the ability to synthesize, store and release GnRH were compromised and contributed to changes in the temporal pattern of neuroendocrine signaling, thereby 

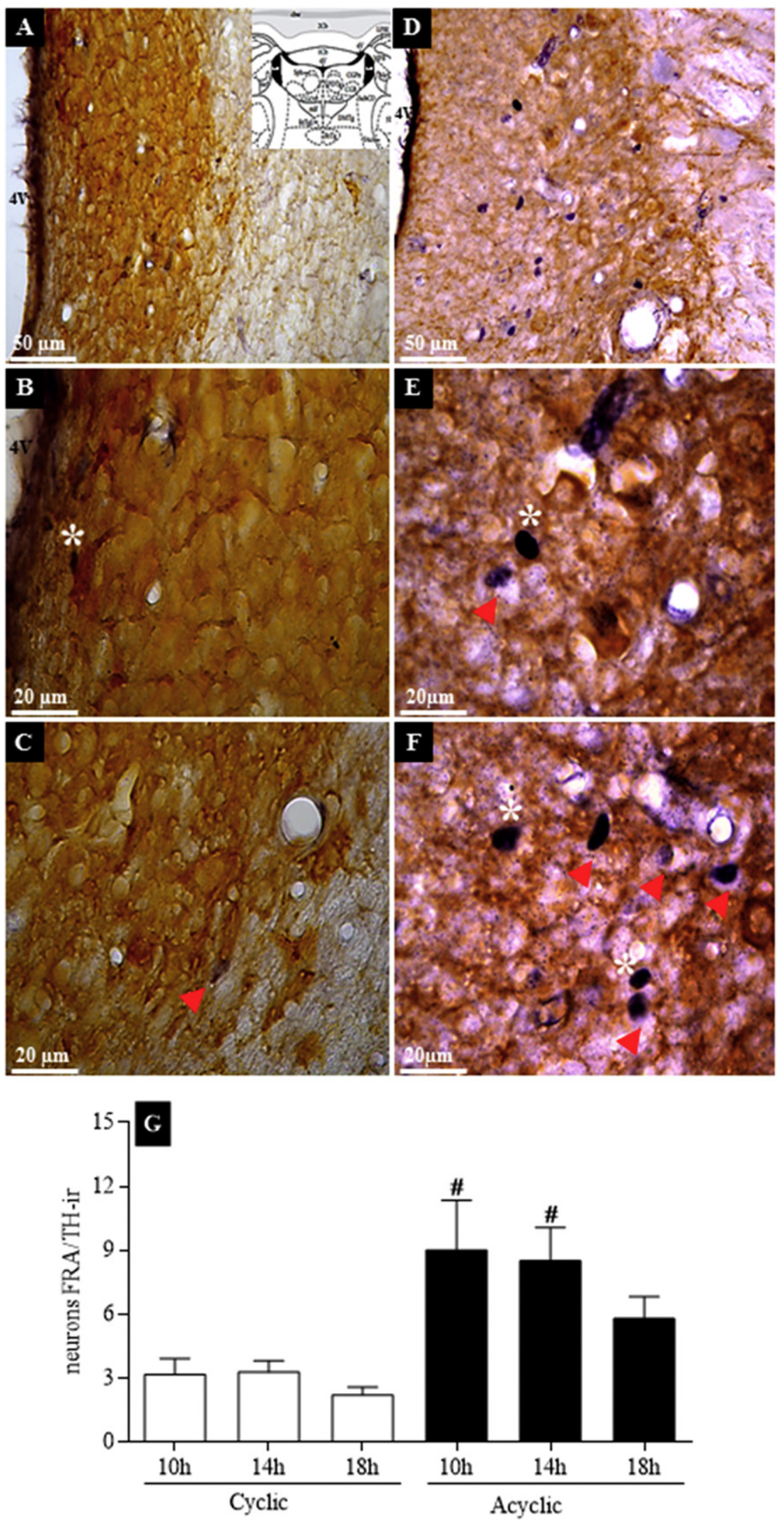

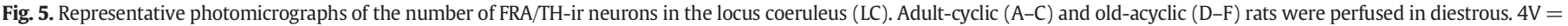

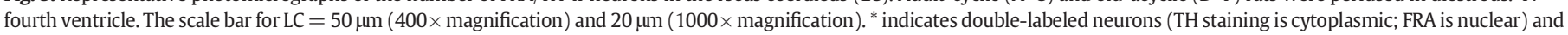

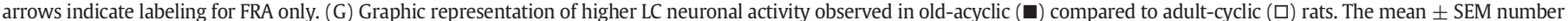
FRA/TH-ir neurons are expressed in the graph. ${ }^{*} p<0.05$ vs. cyclic rats at the same time interval. 

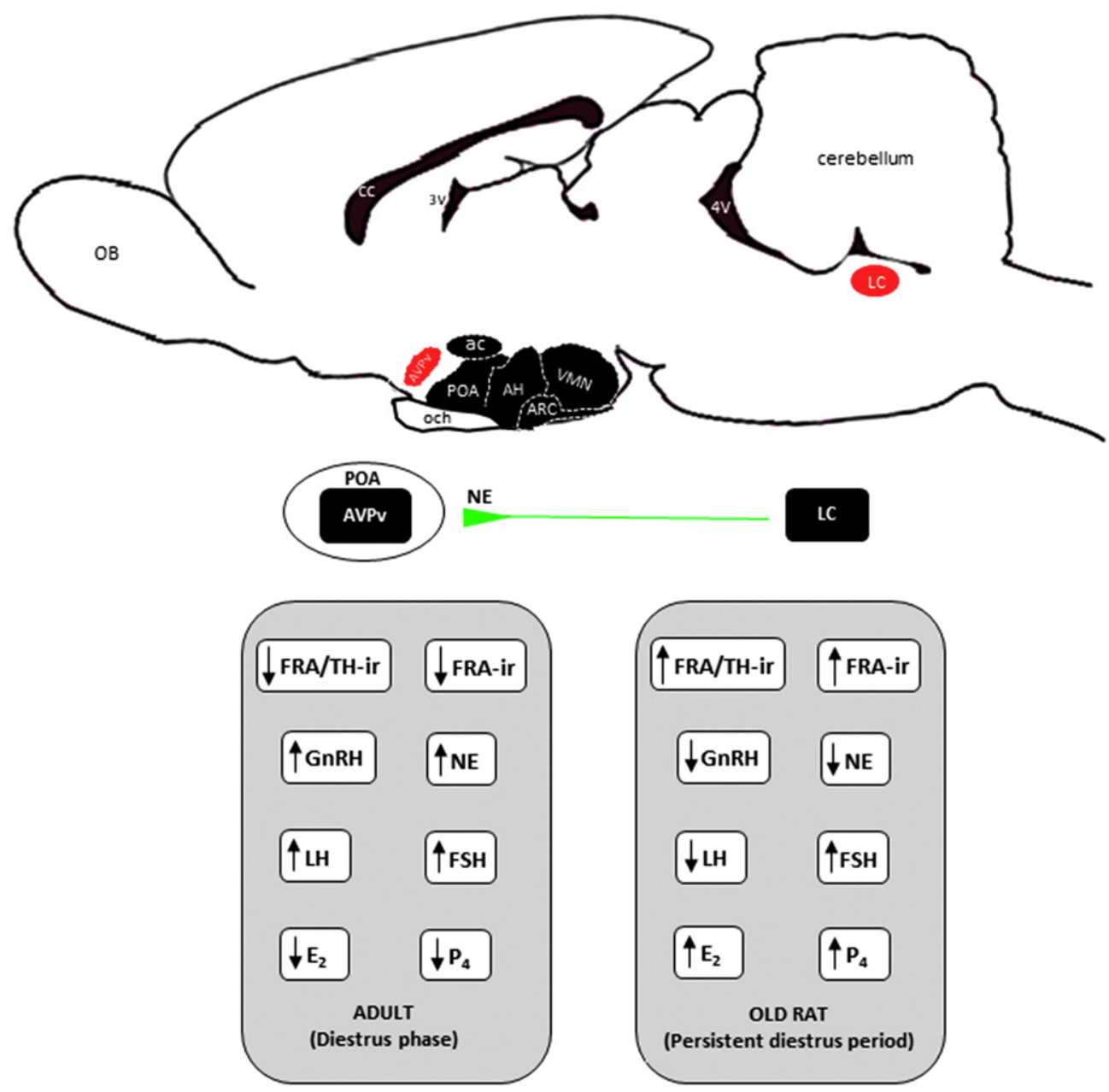

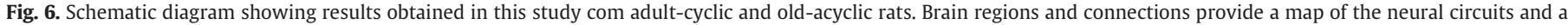
neurobiological basis for the array of that can emerge during periestropause.

compromising the accuracy of inhibitory and stimulatory effects, causing irregularity in the estrous cycle and determining reproductive senescence.

Studies in postmenopausal women have analyzed pituitary response to $\mathrm{GnRH}$ as a function of aging, measuring the amplitude of the pulsatile secretion of LH or exogenous pituitary GnRH response. The decrease in LH pulse amplitude with aging has been documented in some studies (Genazzani et al., 1997; Hall et al., 2000), but it has not been confirmed (Lambalk et al., 1997). It is of interest that the decrease in gonadotropin levels in older compared with adults rats was significant for LH but not for FSH (Fig. 2B and C), in the present study. The authors' results indicated that LH levels reflected a balance between pituitary responsiveness and the hypothalamic GnRH, suggesting that LH secretion was more dependent on GnRH than FSH was. Maybe the FSH levels more closely reflect the effect of aging on the pituitary itself in comparison with $\mathrm{LH}$ whose regulation is more strongly influenced by the complex changes in GnRH secretion (Fig. 6).

In summary, the data of the present study suggest that higher level of activity of the neurons of POA/AVPV and NE neurons of LC in acyclic rats, associated with the lower capacity for the synthesis and storage of neurotransmitters and neurohormones compromises the signaling necessary for the occurrence of maximum secretion of $\mathrm{LH}$ and subsequent ovulation, characterizing the process of reproductive senescence in female rodent.

\section{Disclosure statement}

None of the authors have any actual or potential conflicts to declare.

\section{Acknowledgements}

The authors thank Ruither O.G. Carolino (FORP/USP) for technical assistance, Dr. Celso R. Franci (FMRP/USP) for the RIA facilities, Dr. Sergio Diniz (FMVA/UNESP) for the care of our animals and the Federal Agency of Support and Evaluation of Postgraduate Education (CAPES) and São Paulo State Research Foundation (FAPESP: 2012/14464-6), for the financial support.

\section{References}

Acuña, E., Fornes, R., Fernandois, D., Garrido, M.P., Greiner, M., Lara, H.E., Paredes, A.H. 2009. Increases in norepinephrine release and ovarian cyst formation during ageing in the rat. Reprod. Biol. Endocrinol. 7, 64.

Anselmo-Franci, J.A., Franci, C.R., Krulich, L., Antunes-Rodrigues, J., McCann, S.M., 1997 Locus coeruleus lesions decrease norepinephrine input into the medial preoptic area and medial basal hypothalamus and block the LH, FSH and prolactin preovulatory surge. Brain Res. 767, 289-296.

Anselmo-Franci, J.A., Rocha-Barros, V.M., Franci, C.R., McCann, S.M., 1999. Locus coeruleus lesions block pulsatile LH release in ovariectomized rats. Brain Res. 833, 86-92.

Berridge, C.W., Waterhouse, B.D., 2003. The locus coeruleus-noradrenergic system: modulation of behavioral state and state-dependent cognitive processes. Brain Res. Brain Res. Rev. 42, 33-84.

Bradford, M.M., 1976. A rapid and sensitive method for the quantitation of microgram quantities of protein utilizing the principle of protein-dye binding. Anal. Biochem. $72,248-254$.

Brann, D.W., Mahesh, V.B., 2005. The aging reproductive neuroendocrine axis. Steroids 70 273-283.

Brinton, R.D., 2010. Neuroendocrinology of aging. In: H.M.F., M.D., Rockwood, K. Woodhouse, K. (Eds.), Brockelhurst's Textbook of Geriatric Medicine and Gerontology. Saunders Elsevier. 
Campbell, R.E., Herbison, A.E., 2007. Definition of brainstem afferents to gonadotropinreleasing hormone neurons in the mouse using conditional viral tract tracing. Endocrinology 148, 5884-5890.

Campos, P., Herbison, A.E., 2014. Optogenetic activation of GnRH neurons reveals minimal requirements for pulsatile luteinizing hormone secretion. Proc. Natl. Acad. Sci. U. S. A $111,18387-18392$.

Cashion, A.B., Smith, M.J., Wise, P.M., 2003. The morphometry of astrocytes in the rostral preoptic area exhibits a diurnal rhythm on proestrus: relationship to the luteinizing hormone surge and effects of age. Endocrinology 144, 274-280.

Cora, M.C., Kooistra, L., Travlos, G., 2015. Vaginal cytology of the laboratory rat and mouse: review and criteria for the staging of the estrous cycle using stained vaginal smears. Toxicol. Pathol. 43, 776-793.

Council, N.R., 2011. Guide for the Care and Use of Laboratory Animals. The Nationa Academies Press, Washington.

Diaz Brinton, R., 2012. Minireview: translational animal models of human menopause: challenges and emerging opportunities. Endocrinology 153, 3571-3578.

Donner, N., Handa, R.J., 2009. Estrogen receptor beta regulates the expression of tryptophan-hydroxylase 2 mRNA within serotonergic neurons of the rat dorsal raphe nuclei. Neuroscience 163, 705-718.

Downs, J.L., Wise, P.M., 2009. The role of the brain in female reproductive aging. Mol. Cell. Endocrinol. 299, 32-38.

Dungan, H.M., Gottsch, M.L., Zeng, H., Gragerov, A., Bergmann, J.E., Vassilatis, D.K., Clifton, D.K., Steiner, R.A., 2007. The role of kisspeptin-GPR54 signaling in the tonic regulation and surge release of gonadotropin-releasing hormone/luteinizing hormone. J. Neurosci. 27, 12088-12095.

Ferreira, L.B., de Nicola, A.C., Anselmo-Franci, J.A., Dornelles, R.C., 2015. Activity of neurons in the preoptic area and their participation in reproductive senescence: preliminary findings. Exp. Gerontol. 72, 157-161.

Finch, C.E., 2014. The menopause and aging, a comparative perspective. J. Steroid Biochem. Mol. Biol. 142, 132-141.

Franceschini, I., Desroziers, E., 2013. Development and aging of the kisspeptin-GPR54 system in the mammalian brain: what are the impacts on female reproductive function? Front. Endocrinol. (Lausanne) 4, 22.

Genazzani, A.D., Petraglia, F., Sgarbi, L., Montanini, V., Hartmann, B., Surico, N., Biolcati, A. Volpe, A., Genazzani, A.R., 1997. Difference of LH and FSH secretory characteristics and degree of concordance between postmenopausal and aging women. Maturitas 26, 133-138.

Gianetti, E., Seminara, S., 2008. Kisspeptin and KISS1R: a critical pathway in the reproductive system. Reproduction 136, 295-301.

Hall, J.E., Lavoie, H.B., Marsh, E.E., Martin, K.A., 2000. Decrease in gonadotropin-releasing hormone $(\mathrm{GnRH})$ pulse frequency with aging in postmenopausal women. J. Clin. Endocrinol. Metab. 85, 1794-1800.

Han, S.K., Herbison, A.E., 2008. Norepinephrine suppresses gonadotropin-releasing hormone neuron excitability in the adult mouse. Endocrinology 149, 1129-1135.

Harlow, S.D., Gass, M., Hall, J.E., Lobo, R., Maki, P., Rebar, R.W., Sherman, S., Sluss, P.M., de Villiers, T.J., Group, S.C., 2012. Executive summary of the stages of reproductive aging workshop + 10: addressing the unfinished agenda of staging reproductive aging. J. Clin. Endocrinol. Metab. 97, 1159-1168.

Helena, C.V., de Oliveira Poletini, M., Sanvitto, G.L., Hayashi, S., Franci, C.R., AnselmoFranci, J.A., 2006. Changes in alpha-estradiol receptor and progesterone recepto expression in the locus coeruleus and preoptic area throughout the rat estrous cycle. J. Endocrinol. 188, 155-165.

Herbison, A.E., 1997. Noradrenergic regulation of cyclic GnRH secretion. Rev. Reprod. 2 $1-6$.

Hosny, S., Jennes, L., 1998. Identification of alpha1B adrenergic receptor protein in gonadotropin releasing hormone neurones of the female rat. J. Neuroendocrinol. 10, 687-692.

Ibrahim, B.A., Briski, K.P., 2014. Role of dorsal vagal complex A2 noradrenergic neurons in hindbrain glucoprivic inhibition of the luteinizing hormone surge in the steroidprimed ovariectomized female rat: effects of 5-thioglucose on A2 functiona biomarker and AMPK activity. Neuroscience 269, 199-214.

Lambalk, C.B., de Boer, L., Schoute, E., Popp-Snyders, C., Schoemaker, J., 1997. Postmenopausal and chronological age have divergent effects on pituitary and hypothalamic function in episodic gonadotrophin secretion. Clin Endocrinol (Oxf) 46 439-443.

Le Saux, M., Morissette, M., Di Paolo, T., 2006. ERbeta mediates the estradiol increase of D2 receptors in rat striatum and nucleus accumbens. Neuropharmacology 50, 451-457.

Le, W.W., Wise, P.M., Murphy, A.Z., Coolen, L.M., Hoffman, G.E., 2001. Parallel declines in Fos activation of the medial anteroventral periventricular nucleus and LHRH neurons in middle-aged rats. Endocrinology 142, 4976-4982.
Leite, C.M., Szawka, R.E., Anselmo-Franci, J.A., 2008. Alpha-oestrogen and progestin receptor expression in the hypothalamus and preoptic area dopaminergic neurones during oestrous in cycling rats. J. Neuroendocrinol. 20, 110-119.

Lookingland, K.J., Ireland, L.M., Gunnet, J.W., Manzanares, J., Tian, Y., Moore, K.E., 1991. 3Methoxy-4-hydroxyphenylethyleneglycol concentrations in discrete hypothalamic nuclei reflect the activity of noradrenergic neurons. Brain Res. 559, 82-88.

MacKinnon, P.C., Clement, E.M., Clark, C., Sheaves, R., 1983. Hypothalamic adrenergic activity precedes the preovulatory luteinizing hormone surge in the rat. Neurosci. Lett. 43, 221-226.

Mitsushima, D., Shwe, T.T., Funabashi, T., Shinohara, K., Kimura, F., 2002. GABA release in the medial preoptic area of cyclic female rats. Neuroscience 113, 109-114.

Mize, A.L., Alper, R.H., 2002. Rapid uncoupling of serotonin-1A receptors in rat hippocampus by 17 beta-estradiol in vitro requires protein kinases A and C. Neuroendocrinology 76, 339-347.

Mize, A.L., Poisner, A.M., Alper, R.H., 2001. Estrogens act in rat hippocampus and frontal cortex to produce rapid, receptor-mediated decreases in serotonin 5-HT(1A) receptor function. Neuroendocrinology 73, 166-174.

MohanKumar, S.M., MohanKumar, P.S., 2004. Aging alters norepinephrine release in the medial preoptic area in response to steroid priming in ovariectomized rats. Brain Res. 1023, 24-30.

Neal-Perry, G., Nejat, E., Dicken, C., 2010. The neuroendocrine physiology of female reproductive aging: an update. Maturitas 67, 34-38.

Neal-Perry, G.S., Zeevalk, G.D., Santoro, N.F., Etgen, A.M., 2005. Attenuation of preoptic area glutamate release correlates with reduced luteinizing hormone secretion in middle-aged female rats. Endocrinology 146, 4331-4339.

Osterlund, M.K., Halldin, C., Hurd, Y.L., 2000. Effects of chronic 17beta-estradiol treatment on the serotonin 5-HT(1A) receptor mRNA and binding levels in the rat brain. Synapse $35,39-44$.

Palkovits, M., 1973. Isolated removal of hypothalamic or other brain nuclei of the rat. Brain Res. 59, 449-450.

Paxinos, G., Watson, C., 2007. The Rat Brain in Stereotaxic Coordinates. Academic Press, London.

Petricka, J.J., Benfey, P.N., 2011. Reconstructing regulatory network transitions. Trends Cell Biol. 21, 442-451.

Rubin, B.S., 2000. Hypothalamic alterations and reproductive aging in female rats: evidence of altered luteinizing hormone-releasing hormone neuronal function. Biol. Reprod. 63, 968-976.

Rubin, B.S., Bridges, R.S., 1989. Alterations in luteinizing hormone-releasing hormone release from the mediobasal hypothalamus of ovariectomized, steroid-primed middleaged rats as measured by push-pull perfusion. Neuroendocrinology 49, 225-232.

Sellix, M.T., Menaker, M., 2011. Circadian clocks in mammalian reproductive physiology: effects of the "other" biological clock on fertility. Discov. Med. 11, 273-281.

Shaw, N.D., Srouji, S.S., Histed, S.N., Hall, J.E., 2011. Differential effects of aging on estrogen negative and positive feedback. Am. J. Physiol. Endocrinol. Metab. 301, E351-E355.

Shaw, N.D., Srouji, S.S., Histed, S.N., McCurnin, K.E., Hall, J.E., 2009. Aging attenuates the pituitary response to gonadotropin-releasing hormone. J. Clin. Endocrinol. Metab. 94, 3259-3264.

Szawka, R.E., Helena, C.V., Rodovalho, G.V., Monteiro, P.M., Franci, C.R., Anselmo-Franci, J.A., 2005. Locus coeruleus norepinephrine regulates the surge of prolactin during oestrus. J. Neuroendocrinol. 17, 639-648.

Szawka, R.E., Poletini, M.O., Leite, C.M., Bernuci, M.P., Kalil, B., Mendonça, L.B., Carolino, R.O., Helena, C.V., Bertram, R., Franci, C.R., Anselmo-Franci, J.A., 2013. Release of norepinephrine in the preoptic area activates anteroventral periventricular nucleus neurons and stimulates the surge of luteinizing hormone. Endocrinology 154, 363-374.

Szawka, R.E., Rodovalho, G.V., Monteiro, P.M., Carrer, H.F., Anselmo-Franci, J.A., 2009. Ovarian-steroid modulation of locus coeruleus activity in female rats: involvement in luteinising hormone regulation. J. Neuroendocrinol. 21, 629-639.

Wang, W., Bai, W., Cui, G., Jin, B., Wang, K., Jia, J., Da, Y., Qin, L., 2015. Effects of estradiol valerate and remifemin on norepinephrine signaling in the brain of ovariectomized rats. Neuroendocrinology 101, 120-132.

Watson, R.E., Wiegand, S.J., Clough, R.W., Hoffman, G.E., 1986. Use of cryoprotectant to maintain long-term peptide immunoreactivity and tissue morphology. Peptides 7, 155-159.

Williams, W.P., Kriegsfeld, L.J., 2012. Circadian control of neuroendocrine circuits regulating female reproductive function. Front. Endocrinol. (Lausanne) 3, 60

Yin, W., Wu, D., Noel, M.L., Gore, A.C., 2009. Gonadotropin-releasing hormone neuroterminals and their microenvironment in the median eminence: effects of aging and estradiol treatment. Endocrinology 150, 5498-5508. 